$$
\begin{gathered}
\text { In the Shadow of the } \\
\text { Mexican Revolution: } \\
\text { Contemporary Mexican History, } \\
1910-1989
\end{gathered}
$$


1LS Translations from Latin America Series

Institute of Latin American Studies

University of Texas at Austin 


\section{In the Shadow of the Mexican Revolution: Contemporary Mexican History, 1910-1989}

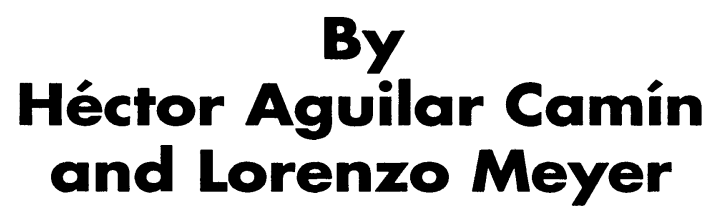

Translated by Luis Alberto Fierro

4 University of Texas Press, Austin 
Copyright $(\mathcal{C} 1993$ by the University of Texas Press

All rights reserved

Printed in the United States of America

Fifth paperback printing, 2001

Requests for permission to reproduce material from this work should be sent to Permissions, University of Texas Press, P.O. Box 7819, Austin, Texas 78713-7819

\section{Library of Congress Cataloging-in-Publication Data}

Aguilar Camín, Héctor, 1946-

[A la sombra de la Revolución Mexicana. English]

In the shadow of the Mexican revolution : contemporary Mexican history, 19101989 / by Héctor Aguilar Camín and Lorenzo Meyer ; translated by Luis Alberto Fierro.

p. cm. - (Translations from Latin America Series)

Includes bibliographical references and index.

ISBN 0-292-70451-8 (pbk.)

1. Mexico-History-20th century. I. Meyer, Lorenzo. II. Title. III. Series. F1234.A22513 1993

$972.08-\mathrm{dc} 20$ 